\title{
Fiscal Decentralization, Economic Growth and Regional Development Inequality in Eastern Indonesia
}

\author{
${ }^{* 1}$ Farida, Nur, ${ }^{2}$ Suman, Agus \& ${ }^{3}$ Sakti, Rachmad Kresna \\ ${ }^{*}$ Pemerintah Kota Kediri, Indonesia \\ ${ }^{2}$ Faculty of Economics and Business, Universitas Brawijaya,Malang, Indonesia \\ ${ }^{3}$ Faculty of Economics and Business, Universitas Brawijaya,Malang, Indonesia \\ Note: * Indicates corresponding author
}

\begin{tabular}{|c|c|}
\hline ARTICLE DETAILS & ABSTRACT \\
\hline $\begin{array}{l}\text { Article History } \\
\text { Published Online: publisher use } \\
\text { only }\end{array}$ & \multirow{4}{*}{$\begin{array}{l}\text { This study analyzes the relations between fiscal decentralization, } \\
\text { economic growth, and regional development inequality in Eastern } \\
\text { Indonesia using 2016-2019 panel data of thirteen Eastern } \\
\text { Indonesia provinces obtained from Statistics Indonesia and the } \\
\text { Directorate General for Fiscal Balance. Using simultaneous } \\
\text { equations estimated through the Three-Stage Least Squares, this } \\
\text { study finds that fiscal decentralization has not fully supported } \\
\text { economic growth and correct the inequality in eastern Indonesia's } \\
\text { regional development. The mandate for managing the budget has } \\
\text { not been optimally used by the local governments, indicated by } \\
\text { poor allocation for productive expenditures and its decreasing } \\
\text { proportion during the research period. It is caused by poor human } \\
\text { resource quality in budget planning and management, which } \\
\text { finally hinders the quality of public service and economic growth. } \\
\text { Supports from physical and human capital are required to keep up } \\
\text { with the occurring economic activities so that inequality in regional } \\
\text { development in the area can be reduced. }\end{array}$} \\
\hline $\begin{array}{l}\text { Keywords } \\
\text { Fiscal decentralization, Local } \\
\text { government expenditures, Regional } \\
\text { development inequality, 3SLS. }\end{array}$ & \\
\hline "Corresponding Author & \\
\hline Email: androida.2323@gmail.com & \\
\hline
\end{tabular}

\section{Introduction}

Indonesia, with its abundance of natural resources, has not been able to provide equitable welfare to all levels of society. All kinds of prosperity in Indonesia are concentrated on the island of Java, causing differences in socioeconomic conditions between Western and Eastern Indonesia as indicated by economic activities, quality of human resources, public service, and completeness of infrastructure. The unequal distribution of development outcomes creates injustice, especially in areas with its abundance of natural resources potential, national policies do not transform local natural wealth as an instrument to improve the welfare of local communities (Tadjoeddin et al., 2003). The high poverty rate in Eastern Indonesia is inversely proportional to the wealth of natural resources it has. According to Foster et al. (1984), the measure of inequality is closely related to the measure of poverty, therefore the issue of inequality is often associated with poverty. Inequality also causes tension in a country that threatens sustainable growth in the long term through various social, political, and economic mechanisms (Fan et al., 2011).

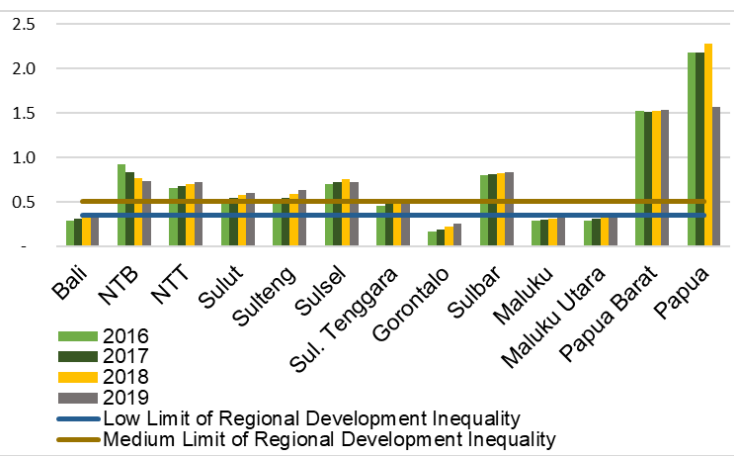

Picture 1. Regional Development Inequality in Eastern Indonesia

Source: Statistics Indonesia (processed)

Economic growth as one of the important indicators determining the success of development aspect has always been the main target in increasing productivity in the economic activities which are expected to have a trickledown effect on people's welfare. However, welfare not only requires high economic growth but equitable distribution (Todaro and Smith, 2006). As a solution, the government should have the same priority between accelerating 
economic growth and efforts to equalize among the regions that are focused in underdeveloped areas (Mahardiki and Santoso, 2013). Failure to reduce inequality in economic growth can also be caused by infrastructure development that is concentrated in certain areas (Chotia and Rao, 2017).

The government's efforts to reduce inequality are relevant to the objectives of decentralization. The enactment of Law number 22 of 1999 concerning Regional Government and Law number 25 of 1999 concerning Financial Balance between Central and Local Governments marked the enactment of a new paradigm of regional autonomy and fiscal decentralization as an intact decentralization. Fiscal decentralization in Indonesia has been effective since January $1^{\text {st }}, 2001$ with broad consequences for local governments to accept the mandate for managing, planning, and implementing their respective regional budget management, followed by the mandate for managing regional revenue sources such as tax bases and transfer funds according to the money follows function mechanism. According to Mardiasmo (2009), the mandate for managing the revenue sources has the following objectives: reducing the fiscal gap among the regions and between the central and local governments, improving the quality of public services, improving the efficiency of national resources enhancement, the allocation of transfer funds that are on target and to provide fiscal sustainability support.

However, during the research period 2016 to 2019, many facts show that regional development inequality is getting worse, supporting the findings of Aritenang (2012), Rodriguez and Ezcurra (2009), Song (2013), Liu et al. (2014), and Arham (2014), which at that period was an era of fiscal decentralization, even nearly two decades, which should have been able to fix these problems, especially since inequality is also a target of the Sustainable Development Goals (SDGs) as a global development agreement. Therefore, it is important to re-analyze the relationship between fiscal decentralization, economic growth, and regional development inequality in Eastern Indonesia.

\section{Literature Review}

According to Sukirno (2010), regional development inequality is a gap in welfare created due to different levels of development in various regions caused by differences in endowment factors. According to Sjafrizal (2012), the causes of development inequality among the regions are differences in natural resources; differences in demographic factors including the quality of human resources (education, health), employment conditions, the work culture of the local community; obstruction of access to the flow of goods and services; concentration of economic activity; and allocation of interregional development funds. The measure of regional development inequality in this study was measured using the Williamson Index with the following formula:

$$
I W=\frac{\sqrt{\sum(Y i-Y)^{2} \frac{F i}{n}}}{Y}
$$

Where:
IW : Williamson Index
$Y i \quad$ : GRDP Per Capita of Regency $i$
$Y \quad:$ : Average GRDP Per Capita of Province
$F i \quad$ : Population of Regency $i$
$n \quad$ : Population of Province

The government steps to achieve proequality economic growth requires the support of efficient public services. According to Tiebout (1956) and Oates (1972), the most efficient public service providers should have areas with minimum geographic control. This is because the local government gets the needs of its people; In responding to community needs, local governments are encouraged to make efficient use of funds originating from the community; Local governments will be stimulated to increase innovation because of competition among the regions in serving the community.

Decentralization is the delegation of authority from the central government to local governments (Mawhood, 1987). Litvack (1999) distinguishes decentralization into political decentralization, administrative decentralization, and fiscal decentralization. According to Mardiasmo (2009), political decentralization is the foundation for the realization of democratization and increasing people's participation in government; administrative decentralization is an instrument used in providing services to the community; while fiscal decentralization functions to ensure the realization of political decentralization and administrative decentralization through the mandate for managing in the budget sector. The delegation of authority in fiscal decentralization brings the necessary budgetary consequences in a kind of funding sources and also central government's transfer according to the money follows function mechanism to carry out the mandates. One of the fiscal decentralization objectives according to Mardiasmo (2009) is to improve the quality and reduce disparities in public services both in the region and among the regions. According to Musgrave (1959), there 
are three functions of fiscal policy implemented by the government: allocation function, the government as a provider of public goods and services; distribution function which the government must emphasize fairness and propriety in budget policies; a stabilization function that makes the government budget an instrument in maintaining and realizing a balance of economic fundamentals.

The theory of fiscal federalism proposed by Oates (1993) explains the relationship between decentralization and economy, public services, and the welfare of society. This theory emphasizes that the delegation of authority to local governments in fiscal decentralization can encourage economic growth and improve the welfare of local communities because local governments are regarded as more efficient in producing or providing public goods (Oates, 1972).

According to the theorem of fiscal decentralization, due to information asymmetry and better insight into local people's preferences, local governments are considered to be more capable than the central government to adjust the provision of public goods and services according to local people's preferences. Therefore, fiscal decentralization is very relevant to be associated with efforts to correct regional development inequality. In addition, the enhancement of the quality of public services also supports an investment climate that contributes to increasing economic growth

\section{Research Method}

This study uses secondary data from the Directorate General of Fiscal Balance and Statistics Indonesia using 2016-2019 panel data of thirteen Eastern Indonesia provinces. The variables used are regional development inequality measured using The Williamson Index, economic growth, government spending, domestic investment, Human Development Index (HDI), labor, GRDP of agriculture, forestry and fishing.

The technique used is a simultaneous equation model which is estimated using the Three Stage Least Square (3SLS) method. According to Chow in Ekananda (2016), there are two reasons that simultaneous equation is suitable to use: this model is suitable to be applied in various economic applications; this model also uses a stochastic model that is suitable for testing economic theory and economic relations based on statistical tests. In addition, the simultaneous equation model provides a better description of the reality than the single equation model (Ekananda, 2016). According to Gujarati (2013), the simultaneous equation model has more than one equation and among the equations have a relationship. Meanwhile, the Three Stage Least Square (3SLS) method is regarded as adequate for providing parameters that consider all relationships among the variables as shown in the model. This method also has more complete information and produces more efficient estimates. The model specifications can be written as follows:

a. Economic Growth Equation

$$
\begin{aligned}
& \text { Growth }_{i t}=\alpha_{0}+\alpha_{1} \text { ln GovSpend }_{i t}+ \\
& \alpha_{2} \text { ln DomInvest }_{i t}+\alpha_{3} \text { HDI }_{i t}+ \\
& \alpha_{4} \ln \text { Labor }_{i t}+\varepsilon_{1}
\end{aligned}
$$

b. Regional Development Inequality Equation

$$
\begin{aligned}
& \text { Inequality } \left.\left._{i t}=\right]_{0}+\right]_{1} \text { Growth }_{i t}+ \\
& \text { ? }_{2} \ln \operatorname{GrdpAgri}_{i t}+\text { ? }_{3} \mathrm{HDI}_{i t}+\varepsilon_{2}
\end{aligned}
$$

Where :

$\begin{array}{ll}\text { Growth } & \text { : Economic Growth } \\ \text { Inequality } & \text { : Regional Development Inequality } \\ \text { GovSpend } & \text { : Local Government Spending } \\ \text { DomInvest } & \text { : Domestic Investment } \\ \text { HDI } & \text { : Human Development Index } \\ \text { Labor } & : \text { Labor } \\ \text { GrdpAgri } & : \text { Gross Regional Domestic Product } \\ & \text { of Agriculture Forestry and Fishing } \\ \alpha, \text { a } & : \text { Constant Coefficient } \\ i & : \text { Unit Index } \\ t & : \text { Time Index } \\ \varepsilon & : \text { Error Term }\end{array}$

\section{Result and Discussion}

\subsection{Result}

Table 1. Parameter Estimation Results

\begin{tabular}{lll}
\hline \multicolumn{1}{c}{ Variable } & Coefficient & Prob. \\
\hline Growth & & \\
In GovSpend & -3.959429 & $0.000^{* * *}$ \\
In Domlnvest & -0.1446205 & 0.427 \\
HDI & 0.066118 & 0.597 \\
In Labor & 1.82582 & $0.002^{* \star *}$ \\
Constant & 94.47895 & $0.000^{* * *}$ \\
\hline Inequality & \\
Growth & -0.1472239 & $0.000^{* * *}$ \\
In GrdpAgri & 0.1595041 & 0.107 \\
HDI & -0.0709894 & $0.001^{* * *}$ \\
Constant & 1.484248 & 0.634 \\
\hline Note : ${ }^{* * *}$ significant on $\alpha=1 \%,{ }^{* *}$ significant on $\alpha=5 \%$, \\
* significant on $\alpha=10 \%$. \\
Source: Stata 16 (processed)
\end{tabular}

In the first equation model, economic growth is influenced by In local government spending, In domestic investment, $\mathrm{HDI}$, and In labor. Based on table 1, it was found that the domestic investment variable and HDI were not significant in influencing economic growth because the probability value was greater than $10 \%$, meaning that the coefficient value of these variables was believed to be zero compared to the estimated 
coefficient value. Meanwhile, there is a significant effect of the variable In local government spending and In labor on economic growth at an error level of less than $1 \%$. Variable In local government spending has a coefficient with a negative sign which means that an increase of $1 \%$ of total local government spending reduces the rate of $\mathrm{e}$

conomic growth by around $3.959429 \%$. Meanwhile, the coefficient of In labor variable is positive which can be interpreted that an increase of $1 \%$ of the total labor will increase economic growth by $1.82582 \%$. The value of the constant-coefficient is 94,47895 means that if all variables are zero, then the level of inequality in regional development is 94,47895 points.

In the second equation model, regional development inequality is influenced by economic growth, In GRDP of agriculture, forestry and fishing, and HDI. Variable In GRDP of agriculture, forestry and fishing and the constant proved not significant in influencing regional development inequality. This is because the $p$-value is greater than $10 \%$, therefore the coefficients of each of these variables are believed to be zero compared to the estimated coefficient values. Meanwhile, economic growth and HDI significantly affect regional development inequality with an error term of less than $1 \%$. The economic growth rate has a coefficient value of -0.1472239 which can be interpreted when economic growth increases by $1 \%$, the regional development inequality rate will decrease by 0.1472239 points. The HDI variable has a coefficient of -0.0709894 which means that if the $\mathrm{HDI}$ value increases by $1 \%$, the regional development inequality will decrease by 0.0709894 points.

\subsection{Discussion}

The effect of local government spending on economic growth is negative, supporting the empirical analysis by Rodríguez-Pose and Ezcurra (2011) and Badrudin (2011). The enhancement of local government spending in Eastern Indonesia will be accompanied by a reduction in economic growth in the region. Local government spending is the main variable that represents fiscal decentralization because fiscal decentralization in Indonesia is decentralization by the expenditure side. On the theory of fiscal federalism, local governments will behave differently when receiving mandates from the central government in decentralization, local governments will try to further improve the welfare of local communities. Welfare will be maximized if each local government provides public goods. Fiscal decentralization can increase economic growth and welfare levels because local governments are considered to be

Faculty of Economics and Business,

Brawijaya University more efficient in producing or providing public goods (Oates, 1972). This is due to the possibility that there are similarities in the provision of public goods for all regions that are not necessarily needed by the community if provided by the central government. Through local governments, the outputs and outcomes of public goods provided will bring more benefits and satisfaction to the local community. The compatibility between what is needed and what is obtained makes the government's budget effective.

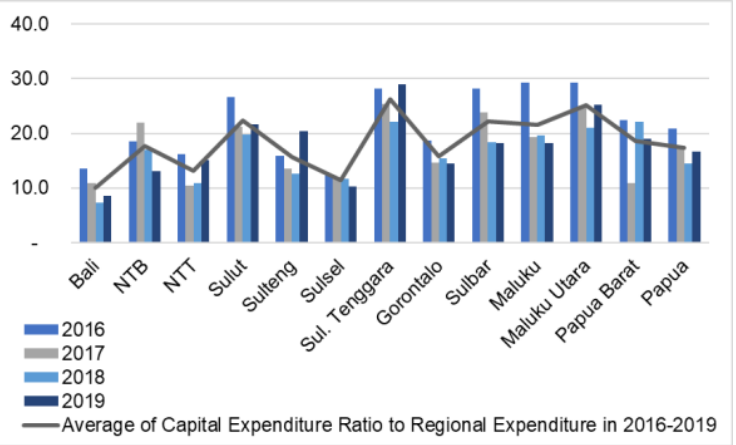

Picture 2. Average of Capital Expenditure to Regional Expenditure in 2016-2019

Source: The Directorate-General for Fiscal Balance (processed)

According to $\mathrm{Li}$ et al. (2017), equitable distribution of all types of public services can encourage the equitable distribution of regional income and consumption. The provision of public goods is one of the improvements in public services that can be realized through capital expenditures. However, the realization of capital expenditures in Eastern Indonesia provinces have not been as expected, the proportion is less than $30 \%$ and has decreased during the study period, supporting the findings of Nugraheni and Priyarsono (2012). Capital expenditure is a government expenditure that has long-term benefits because it adds fixed assets, the lack of equitable public goods provision such as adequate basic infrastructure will hamper economic growth and investment.

Meanwhile, to evaluate local government spending by considering the role of silpa (more/less difference between the realization of the budget realization report revenue and expenditure for one reporting period) on the negative influence of local government spending on economic growth, it was found that eleven out of thirteen provinces in Eastern Indonesia had a fairly good budget absorption above $90 \%$. Thus, it can be concluded that the problem of local government spending lies not in the absorption of spending, but unproductive composition. This study supports the research of Barro (1990), that unproductive government spending has a negative effect on economic growth. The factor 


\section{Fiscal Decentralization, Economic Growth and Regional Development Inequality in Eastern Indonesia}

that plays a role in determining the quality of spending in this area is the weak capacity of human resources in the budget sector, especially planners and budget makers. The mechanism for planning, compiling, determining, and implementing the budget is very important, therefore a qualified human resource capacity is needed to ensure the quality of outputs and outcomes are more measurable, transparent, accountable, effective, and efficient. This is to avoid uncontrolled spending or deviations from the budget.

According to the World Bank and Martinez \& McNab in Khusaini (2006), fiscal decentralization can be a trigger for macroeconomic instability that disrupts economic growth because it reduces government spending and taxes based on the central government which is generally used for the stabilization function. The impact of fiscal decentralization on economic growth between developed and developing countries is also different. The benefits of fiscal decentralization in developing countries are not yet regarded because the institutions do not encourage local governments to use information asymmetry related to their communities. According to Thiessen (2003), fiscal decentralization has several weaknesses, there are increasing regional inequality and hampering economic growth, differences in income levels and tax bases among the regions will encourage differences in the provision of infrastructure, education, health, and other public services and reduce the maximum use of production factors including human capital.

Domestic investment in this study has no significant effect on economic growth. This means that domestic investment is not a determining factor in increasing economic activity in Eastern Indonesia. The possible reason for the low realization of domestic investment is because this area has not been supported by a conducive investment climate. Most provinces in this region still do not have complete and adequate infrastructure to attract investment, limited human resource skills, relatively isolated geographical constraints, and unsupported licensing procedures. Meanwhile, investment can only develop with the support of adequate public sector efficiency and a conducive economic climate to create a multiplier effect in the economy. This research is not in line with Putri (2014) and Sjafii (2004).

In supporting economic efficiency efforts, domestic investment is another source of financing besides transfer funds from the central government which is expected to be an engine of growth in economic development so that not all development costs are charged to the government budget. The Efficiency of allocation is carried out in collaboration with the private sector according to its role. According to Fan et al. (2011), private investment can provide funding reinforcement and play a role in regional development to encourage economic growth. The investment will increase productivity in economic activity which will play a role in the absorption of labor to reduce unemployment. According to Jhingan (2012), investment can increase the income from the demand side and production capacity in the economy through increasing the capital stock from the demand side.

So far, the quality of human resources is measured by the Human Development Index (HDI). The HDI variable in this study has no significant effect on economic growth, which means that $\mathrm{HDI}$ is not the main determinant in increasing economic growth. The weak influence is possible because of the high cost of realizing the components of the HDI, such as certain quality education and health, and the high purchasing power of the people. This can also occur due to economic decline in the early phase of human capital development before it is finally able to boost productivity. Another possibility is the mobilization of quality human capital to more developed areas, both within and outside the region, causing the areas left behind to lose development capital.

In planning and implementing the development targets, the population as the main capital without adequate skills has not guaranteed fruitfulness. Population quality indicated by the HDI needs to be considered to support the development process. The high and low HDI achievement reflects its quality and ability to absorb and manage production factors that are important for economic growth. This study does not support the findings of Dewi \& Sutrisna (2014).

The labor variable shows a significant effect on economic growth. The large number of labor absorbed in the production process contributes to increasing goods and services in economic activity which will encourage the enhancement of economic growth. By the production function aggregate that economic growth is influenced by factors, one of which is labor. Output per worker will increase if each worker gets capital deepening. This is to prevent the decline of labor productivity due to a lack of capital to work. This study supports the research of Putri (2014) and Lubis (2014).

Economic growth has a negative influence on regional development inequality. This can be interpreted that if economic growth increases, regional development inequality will decrease. According to Williamson (1965), at the beginning 
of economic development, the economy will be concentrated in one or a few growth centers in the region. According to Myrdal (1957), economic development will cause a spillover effect, there will be a flow of development capital to developed regions or areas that are growth centers so that developed regions gain an accumulation of competitive advantage. This provides investment opportunities for several rounds that can accelerate economic growth in developed regions so that underdeveloped regions will hard to compensate because of widening regional development inequality.

Convergence is possible if the spread effect occurs in sustainability development. By focussing on non-economic factors that are the process of cumulative causes of economic change, along with the market size enhancement, economic growth will spread to other areas that have been suppliers of resources so that reducing regional development inequality. This is indicated by several conditions: market saturation which reduces the attractiveness of early growth centers; the increasing of labor demand in underdeveloped areas; government actions to increase and improve the infrastructure facilities in underdeveloped areas. According to Li et al. (2017), an effective way to reduce inequality and improve people's standard of living is by increasing infrastructure facilities and the quality of education, health, and social welfare in underdeveloped areas. This study supports the findings of Mopangga (2011) and Barrios and Strobl (2009).

The GRDP of agriculture, forestry and fishing has no significant effect on regional development inequality in Eastern Indonesia, supporting Zaini's research (2018). The average GRDP contribution of agriculture, forestry and fishing to the total GRDP in Eastern Indonesia during the study period was only $20.33 \%$. For areas with great potential, this contribution is relatively small, although it is the highest achievement compared to other sectors. According to Rachmaningsih and Priyarsono (2012), Eastern Indonesia is an area that has great economic potential, especially in agriculture, but is still constrained on its management due to the limited quality and quantity of human resources. This area is also referred to as sleeping potential because its contribution is not optimal to national economic development, there are still many agricultural and waters resources, flora, and fauna that have not been developed (Nuhung, 2010). The availability of abundant natural resources does not guarantee prosperity, depending on its management (Wright and Czelusta, 2004).

According to Chen and Groenewold (2010), policies to increase productivity or investment in agricultural infrastructure in rural areas have a strong influence on per capita output which can reduce regional inequality and make them more prosperous. The agriculture sector is the most relevant in reducing inequality compared to the industrial and service sectors (Nangarumba, 2015).

In addition, the weak influence of agriculture, forestry and fishing GRDP on regional development inequality in Eastern Indonesia can be caused by the large value of plantation and forestry tax levies in this area which do not become local government revenues but the central government. Then that revenue is returned to the regions through revenue sharing which is the proportion is smaller than the actual contribution. Thus, the status of resource ownership does not guarantee that its contribution can be fully enjoyed for the community welfare in the area.

The HDI variable shows a negative influence on regional development inequality which can be interpreted that if the HDI in Eastern Indonesia increases, then inequality in the region will decrease. The HDI component which consists of education, health, and purchasing power reflects the quality of human resources. According to Sjafrizal (2008), the quality of human resources is one of the factors causing regional development inequality. The average of $\mathrm{HDI}$ achievement in Eastern Indonesia for the last four years is still below the regional and national HDI average. Based on the categories determined by Statistics Indonesia, the majority of provinces HDI in the region are in the medium category and some are even in the low category. The HDI achievement confirms that there is a strong negative relationship to the high level of regional development inequality in the region. The Province of Papua is the lowest $\mathrm{HDI}$ as well as the area with the highest regional development inequality.

$\mathrm{HDI}$ is an important indicator in measuring the quality of human life achievement as a reflection of development fruitfulness which can be explained through how the population can access development outcomes in obtaining income, health, and education. According to the new growth theory, both convergence and divergence can occur depending on the quality of capital, especially human capital as a determinant of productivity. This study is in line with the findings of Nurhuda et al. (2013) that the higher and more equitable HDI will encourage the reduction of regional development inequality. According to Farah and Sari (2014), human capital is one of the factors that affect productivity capabilities which are manifested in the qualitative dimensions of human resources, 
such as expertise and skills that can be obtained through education, training, and health.

\section{Conclusions and Suggestions}

\subsection{Conclusions}

Government spending as a manifestation of the government's work plan that has been prepared is a strategic key to governance. Fiscal decentralization represented by government spending will provide a multiplier effect if the allocation is appropriate to the needs of the community. Public services are very important in supporting economic growth and efforts to correct regional development inequality in Eastern Indonesia, the availability is also an investment attraction. The enhancement of the quality of public services through productive spending has not been fully supported by the government budget. The mandate for managing the budget has not been optimally used by the local governments in decentralization, indicated by poor allocation for productive expenditures compare to the routine. It is caused by poor human resource quality in the budget sector include planning and management, which finally hinders the quality of public service and economic growth. Supports from physical and human capital are required to keep up with the occurring economic activities so that inequality in regional development in the area can be reduced.

Regional fiscal independence has not yet been created in Eastern Indonesia, the ratio of balancing funds to total revenue dominates revenue in this region. However, efforts to achieve independence in fiscal must consider the risks to investment attractiveness which is still weak. It takes a focus on non-economic factors that are the cumulative causes of economic change as well as the carrying capacity of quality physical and human capital to balance ongoing economic activities to encourage pro-equality economic growth. To realize prosperity in Eastern Indonesia, it is necessary to increase the quality of basic infrastructure services to support investment opportunities that can create a multiplier effect.

\subsection{Suggestions}

This study suggests the government increase the capacity of human resources in planning and budget management to upgrade the competence in implementing a performancebased budgeting system that gives more measurable, transparent, accountable, effective, and efficient outputs. It is also necessary to evaluate the allocation of local government spending directed at increasing productive spending in the form of capital spending to support physical capital like public goods or spending on education, health, and other expenditures as investments to improving the quality of human capital in stimulating economic growth and correct regional development inequality.

\section{REFERENCES}

Arham, M. A. (2014). Kebijakan Desentralisasi Fiskal, Pergeseran Sektoral, dan Ketimpangan Antarkabupaten/Kota di Sulawesi Tengah. Jurnal Ekonomi Dan Pembangunan Indonesia, 14(2), 145167.

Aritenang, A. (2012). A Study on Indonesia Regions Disparity: Post Decentralization. SSRN Electronic Journal, December, 1-10.

Badan Pusat Statistik (2017). Statistik Indonesia 2017. Jakarta : BPS

(2018). Statistik Indonesia 2018. Jakarta : BPS

(2019). Statistik Indonesia 2019. Jakarta : BPS

(2020). Produk Domestik Regional Bruto Provinsi-provinsi di Indonesia Menurut Lapangan Usaha 2015-2019. Jakarta : BPS

(2020). Statistik Indonesia 2020. Jakarta :BPS

Badrudin, R. (2011). Effect of Fiscal Decentralization on Capital Expenditure, Growth and Welfare. Economic Journal of Emerging Markets, 3(3), 211-223.

Barrios, S., dan Strobl, E. (2009). The Dynamics of Regional Inequalities. Regional Science and Urban Economics, 39(5), 575-591.

Barro, R. (1990). Government Spending in a Simple Model of Endogenous Growth. Journal of Political Economy, 98 : S103S125.

Chen, A., dan Groenewold, N. (2010). Reducing Regional Disparities in China: An Evaluation of Alternative Policies. Journal of Comparative Economics, 38(2), 189-198.

Chotia, V. dan Rao, N.V. (2017). Investigating The Interlinkages Between Infrastructure Development, Poverty and Rural-Urban Income Inequality: Evidence From Brics Nations. Studies in Economics and Finance, 34(4), 466484.

Ekananda, M. (2016). Analisis Ekonometrika 
Data Panel, Edisi 2. Jakarta: Mitra Wacana Media

Fan, S., Kanbur, R. dan Zhang, X. (2011). China's Regional Disparities: Experience and Policy. Review of Development Finance, 1(1), 47-56.

Farah, A., dan Sari, E. P. (2014). Modal Manusia dan Produktivitas. JEJAK: Journal of Economics and Policy, 7(1), 22-28.

Foster, J., Greer, J. dan Thorbecke, E (1984). A Class of Decomposable Poverty Measures. Econometrica, 52, 761-765.

Gujarati, D (2013). Dasar-dasar Ekonometrika, Edisi Kelima. Mangunsong, R. C. (penerjemah). Jakarta: Salemba Empat.

Jhingan, M. L. (2012). Ekonomi Pembangunan dan Perencanaan. Jakarta : Rajawali Press

Kementerian Keuangan Direktorat Jenderal Perimbangan Keuangan (2020). Realisasi APBD 2016, 2017, 2018 dan 2019.

Khusaini, M. (2006). Ekonomi Publik : Desentralisasi Fiskal dan Pembangunan Daerah. Malang : BPFE Unibraw

Li, B., Li, T., Yu, M. dan Chen, B. (2017). Can Equalization of Public Services Narrow The Regional Disparities in China? A Spatial Econometrics Approach. China Economic Review, 44, 67-78.

Litvack, J. (1999). Decentralization. Washington DC : World Bank.

Liu, Y., Martinez, J., Vasquez, dan Wu, A. M. (2014). Fiscal Decentralization, Equalization and Intra-Provincial Inequality in China. November, 14-32.

Lubis, C. A. B. E. (2014). Pengaruh Jumlah Tenaga Kerja, Tingkat Pendidikan Pekerja dan Pengeluaran Pendidikan Terhadap Pertumbuhan Ekonomi. Jurnal Economia, 10(2), 187-193.

Mahardiki, D., dan Santoso, R. P. (2013). Analisis Perubahan Ketimpangan Pendapatan dan Pertumbuhan Ekonomi Antar Propinsi di Indonesia 2006-2011. JEJAK Journal of Economics and Policy, 6(2), 103-213.

Mardiasmo. (2009). Otonomi dan Manajemen Keuangan Daerah. Yogyakarta: Andi Press.

Mawhood P. (ed) (1987). Local Government in The Third World : The Experience of Tropical Africa. Chicester : Jhon Wiley \& Sons.

Mopangga, H. (2011). Analisis Ketimpangan
Pembangunan dan Pertumbuhan Ekonomi di Provinsi Gorontalo. Trikonomika, 10(1), 40-51.

Musgrave, R.A. (1959). Theory of Public Finance : A Study in Public Economy. New York : McGraw

Myrdal, Gunnar (1957), Teori ekonomi dan daerah tertinggal. London: Hutchinson.

Nangarumba, M. (2015). Analisis Pengaruh Struktur Ekonomi, Upah Minimum Provinsi, Belanja Modal dan Investasi Terhadap Ketimpangan Pendapatan di Seluruh Provinsi di Indonesia Tahun 2005-2014. JESP, 7(2), 9-26.

Nugraheni, D., dan Priyarsono, D. S. (2012). Kinerja Keuangan Daerah, Infrastruktur, dan Kemiskinan: Analisis Kabupaten/Kota di Indonesia 20062009. Jurnal Ekonomi Dan Pembangunan Indonesia, 12(2), 148167.

Nuhung, I. A. (2010). Pertanian, Kemiskinan dan Kawasan Timur Indonesia. Jakarta : PT. Wahyu Promo Citra.

Nurhuda, R., Muluk, M. R. K. dan Prasetyo, W. Y. (2013). Analisis Ketimpangan Pembangunan (Studi di Provinsi Jawa Timur Tahun 2005-2011). Jurnal Administrasi Publik Mahasiswa Universitas Brawijaya, 1(4), 110-119.

Oates, W. E. (1972). Fiscal Federalism. New York : Harcourt Brace Jovanovich

Oates, W.E. (1993). Fiscal Decentralization and Economic Development. National Tax Journal, 46(2), 237-243.

Putri, P. I. (2014). Pengaruh Investasi, Tenaga Kerja, Belanja Modal dan Infrastruktur Terhadap Pertumbuhan Ekonomi di Pulau Jawa. 7(708)

Rachmaningsih, T., dan Priyarsono, D. S. (2012). Ketahanan Pangan di Kawasan Timur Indonesia. Jurnal Ekonomi Dan Pembangunan Indonesia, 13(1), 1-18.

Rodríguez-Pose, A., dan Ezcurra, R. (2009). Does Decentralization Matter for Regional Disparities? A Cross-Country Analysis. Spatial Economic Research Centre, 25(July).

Rodríguez-Pose, A., dan Ezcurra, R. (2011). Is Fiscal Decentralization Harmful for Economic Growth? Evidence From The OECD Countries. Journal of Economic Geography, 11(4), 619-643.

Sjafii, A. (2004). Pengaruh Investasi Fisik dan Investasi Pembangunan Manusia Terhadap Pertumbuhan Ekonomi Jawa Timur 1990-2004. 59-76. 
Sjafrizal. (2008). Ekonomi Regional, Teori dan Aplikasi. Padang: Badouse Media.

Sjafrizal. (2012). Ekonomi Wilayah dan Perkotaan. Jakarta: PT. Raja Grafindo Persada.

Song, Y. (2013). Rising Chinese Regional Income Inequality: The Role of Fiscal Decentralization. China Economic Review, 27, 294-309.

Sukirno, Sadono (2010). Makroekonomi Teori Pengantar. Jakarta: PT. Raja Grafindo Persada.

Tadjoeddin, M. Z., Suharyo, W. I., dan Mishra, S. (2003). Aspiration to Inequality: Regional Disparity and Centre-Regional Conflicts in Indonesia. UNU/WIDER Project Conference on Spatial Inequality in Asia United Nations University Centre, Tokyo, 28-29 March 2003, March.

Thiessen, U. (2003). Fiscal Decentralization and Economic Growth in High Income OECD Countries. Fiscal Studies, Vol. 24 No. 3.

Tiebout, C. (1956). A Pure Theory of Local Expenditures. Journal of Political Economy, 64, 416-424

Todaro, M.P. dan Smith, S.C. (2006). Pembangunan Ekonomi, Jilid 2 (9). Jakarta: Erlangga.

Williamson, J (1965). Regional inequality and the process of national development: A description of the patterns. Economic Development and Cultural Change, 13(4), 1-84.

Wright, G., dan Czelusta, J. (2004). The Myth of the Resource Curse. Chalenge, Vol. 47 (No. 2), 6- 38

Zaini, A. (2018). Pengaruh Kekayaan Sumberdaya Alam Batubara Terhadap Ketimpangan Pendapatan di Provinsi Kalimantan Timur. Jurnal Borneo Administrator, 13(2), 111-130. 